\title{
Integrative Social Movements in Maintaining Sustainable Environmental Development in East Java
}

\author{
${ }^{1}$ Governmental Science, University of Muhammadiyah Malang, Malang, Indonesia \\ ${ }^{2}$ Governmental Science, Majapahit Islamic University, Mojokerto, Indonesia \\ ${ }^{3}$ Student Doctoral Program, Brawijaya University, Malang, Indonesia \\ *Corresponding author. Email: sulis226@gmail.com
}

Tri Sulistyaningsih ${ }^{1 *}$, Suprapto ${ }^{2}$, Saiman ${ }^{1}$, Ahmad Hasan Afandi $^{3}$

\begin{abstract}
This aim of this research is to explain and to make a model of social movements in sustainable environmental development. This research uses the qualitative approach to analyze Focus Group Discussion (FGD) data, interviews, and documentation. This research reveals the management of pollution and its impact on the environment. Social movements for sustainable environmental development must be covered and supported by the involvement of stakeholders, government, society, and the private sector. In addition to strengthen social movements, it is necessary to stroke or implant the environmental ideology, as well as the successfulness and sustainability of the social movements was driven by the success of the leader in mobilizing others and mobilizing the resources that can be obtained. Success in mobilizing others contributes an important role than mobilizing resources. The seriousness and success of leaders in mobilizing resources and other people are popularized by social capabilities and political relations between leaders and the movement of participants. The involvement of stakeholders, government, society, and the private sector is an ideal model in determining the success of social movements.
\end{abstract}

Keywords: social movement, society, government, environmental development

\section{INTRODUCTION}

Based on the socio-ecological approach, pollution from rubber factories has drawn criticism from the community. Even, based on environmental considerations, pollution cannot be justified. Moreover, it is caused by rubber factory waste. As a Salim statement [28], inevitably, natural resources which become new products (factories goods produced), also produce dirt, waste, and residual waste.

The rubber factory's pollution brings conflict and rejection from the community around the factory who got losses. There are two kinds of losses, material and non-material losses. Material losses such as pollution in wells (water), soil, and air. Whether, non-material losses such as skin infections and itching, having asphyxiate, and coughing. Also, the community cannot enjoy their food disturbed by pollution. Observing at some losses, Rosidi [27] emphasizes that there are several external costs, such as pollution costs, social costs, and future costs.

Furthermore, the handling of pollution, the impacts on the environment, and the location assessment of the factory establishment carried out to afford criticism of the existence of the factory. Actions of rejection influenced by actors are an inseparable part of social movements [1] and safety ecologies [2].

As examined, social movements influenced by collective action [3] and resource mobilization [4]. According to Vinthagen and Johansson [5], resistance exists as an open declaration (open rebellion, petition, demonstration, and land invasion). Therefore, this paper aims to identify the research question, specifically: What are the strategies of integrative social movements in sustainable environmental development? What are the integrative social movement model in sustainable environmental development?

\section{LITERATURE REVIEW}

\subsection{Collective action, Actors, Ideology, and Mobilization of Resource}

On the economic reductionism in Marxism approach, social action assumes economic logic and class relations [3],[6]. Whereas, in the holistic approach, Olson [6] pays attention to collective action on rational concerns. Based on this theory, Coleman has placed the structure of action (focus on authority, belief systems, collective behavior, and norms), [7].

However, community structure in the forms of the characteristics of actors over the combination of individualaggregation includes "plurality patterns," "form aspects" of human interaction, or, most commonly, "groups" and "communities." [8]. In the dialectical approach, there are ideas system and distribution of political and social values agreed upon through social relations [9], social life, politics, actions, and social structures [10]. Ideology signifies a set of values, beliefs, assumptions, and expectations [30] which serves as a guide to frame the development paradigm for the community [11].

According to Hummel [12], in a conservative view, beliefs continually adjust the ecological-economic-production process and vice versa. In the same case, Simons [13] show 
how political ideology intersects with the need for resources to produce competition and mutualism between organizations. Besides, Bookchin criticizes anti-ecological trends under the 'social ecology' in the field of anarchist geography to designate 'freedom of ecology' as continuing involvement in environmental justice, resource security, and ecological governance [14].

In general, the mobilization of resources theory develops on the influence of rational action, collective action, and social movements [4],[15],[16][17]. Social movement organizations (SMOs) becomes a resource base from the environment and all the mobilization of resources to support from both the general public and the elite [18]. Strategically, it means that this movement formed by the political environment, [17].

Furthermore, social movements, both the old social movement groups (Marxist) and new social movements (Post-Marxist), become critical studies of the analysis of collective action [3],[19]. As an integral part of the approach for resource mobilization, the social movement organizations [18], the perspective of collective action cannot be separated from the study of aggregation of resources [4]. According to Tilly [15],[16], collective action as such is a function of concerns, organization, resource mobilization, power, repression (or facilitation), and opportunity (or threat).

\subsection{Sustainable Environmental Development}

Environmental studies in the development sector are directed towards sustainability programs. There are 3 (three) pillars as a reinforcement of sustainable development, namely: 1) nature, 2) people, and 3) society [20]. The concept of sustainable environment has a scope of sustainability and complexity. The context of sustainability considers social, organizational, and individual aspects in looking at the natural environment [21] and on the concept of progress based on aspects of the socio-economic market [20].

The progress of sustainable development requires the support of information technology in environmental sustainability. Environmental sustainability strategies by involving information technology allow several digital applications to mark direct and indirect possibilities [22]. Thus, the overall strategy requires the incorporation of related elements such as regional environmental development and social, cultural policies [23].

The link between human relations and nature, the emphasis on sustainable environmental development is serious attention to the effects of pollution, waste and industrial emissions. One of the main environmental problems is the habit of the industrial community to discharge large amounts of wastewater. As a result of the absence or management of industrial waste can endanger human health and the ecosystem, [23]. Along with the strengthening of attention in the environmental field, the direction of sustainable development is environmental, human/ community, and industrial collaboration [20]. This collaboration has the potential for environmental emissions, the use of renewable raw materials, and the elimination of toxic substances [24].

\section{METHOD}

This research uses a qualitative research approach. Data analysis was performed based on field notes which were then reduced, described, analyzed, and interpreted [25]. Data from this study were collected using the following methods: interviews, focus group discussions (FGD), and documentation. Interview questions are based on literature review and secondary data through mass media and YouTube. Interview questions addressed to key informants are determined by purposive sampling. Key informants are chosen based on their position and their important role in conducting social movements. They are the Head of Medali Village, Chairperson of the Environment Community, Community's figures, and Youth Community (Karang Taruna).

This research uses the qualitative approach to analyze Focus Group Discussion (FGD) data, interviews, and documentation. Qualitative approach can assist researchers in categorizing FGD data, interviews, and documentation. Furthermore, qualitative approach used to develop patterns of integrative social movements.

\section{RESULTS AND DISCUSSION}

\subsection{Resource Mobilization and Collective Action}

Based on the analysis of determinants of resource mobilization, the following data described the determinants of social movements in resource mobilization which include: 1) Social Movement Organizations, 2) Leaders and Leadership, 3) Resources and Resource Mobilization, 4) Networks and Participation, and 5) Opportunities and Community Capacity.

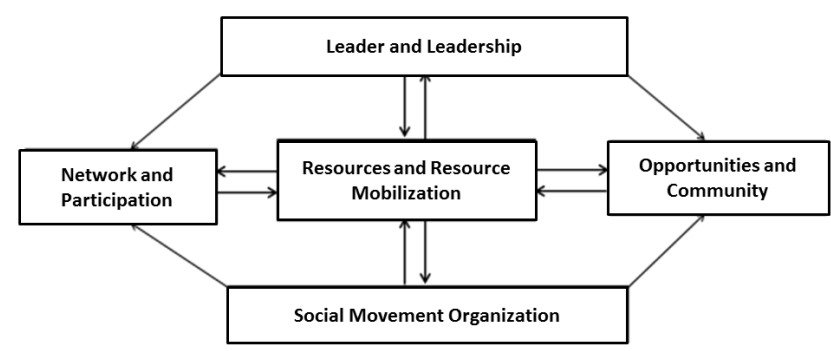

Figure 1 Determinant factors of social movement in resource mobilization

Figure 1. Illustrates the linkages of resources and resource mobilization with other determinant factors. The determinant factor also has connections to resources and resource mobilization. On the organizational social movements and leaders \& leadership factors, it influences networks and participation, as well as opportunities and community capacities.

Based on the assumption, the higher the emotional involvement level of parties in a conflict, the more likely the conflict to be violent, Simmel [29]. The emotional level 
of the Medali's community is supported by a sense of solidarity and protest.

Observing the incident, the actors, in this case, were the Head of Medali Village, Chairperson of the Environment Community, Community's figures, and Youth Community (Karang Taruna). Therefore, village officials and local community leaders unite citizens to understand the interests in the environmental field through collective action and resource mobilization.

The following data is the illustration of the collective action of social movements analysis from four value-added models in collective action: 1) structural conduciveness, 2) structural tension, 3) growth and dissemination of general trust, and 4) social control operations [18].

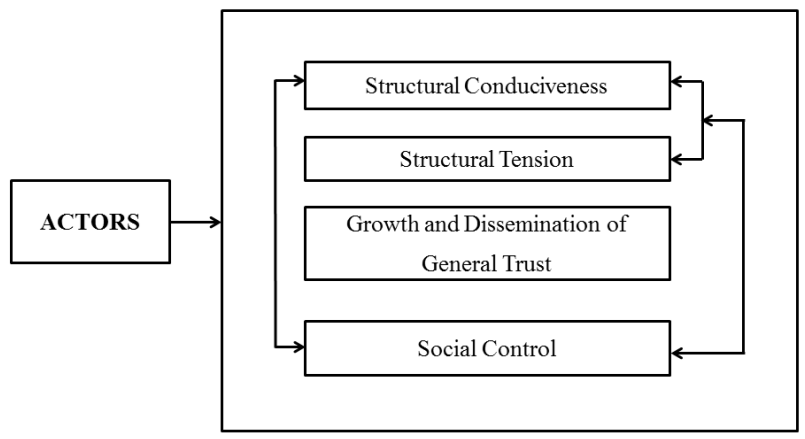

Figure 2 Analysis of the collective action of social movements

Figure 2. describe the involvement of actors in collective action. In this case, actors influence structural conduciveness, structural tension, growth, and spread of public trust, and the operation of social control in the practice of collective action. However, the operation of social control influenced by aspects of structural conduciveness and structural tension. Based on the four elements of collective action, elements of structural conduciveness, growth, and spread of public trust have dominant influences on the actors

\subsection{Design of Integrative Social Movement Models}

The social movements phenomenon undertaken by citizens besides the economic field is critical of development. In this case, development according to this research is the environmental field. As a comparison, there were protests by the community, for example, the turn of Kendeng mountains into cement factories, the construction of NYIA in Jogja, the conflict between the TNI and the Farmers in Urut Sewu, and the heap of hospital waste by PT. MEN in Lakardowo Mojokerto. The following data describe the logical chronological process of social movements that include elements of the structural context, movement structure, strategy, protest activities, and results (outcome) [26].

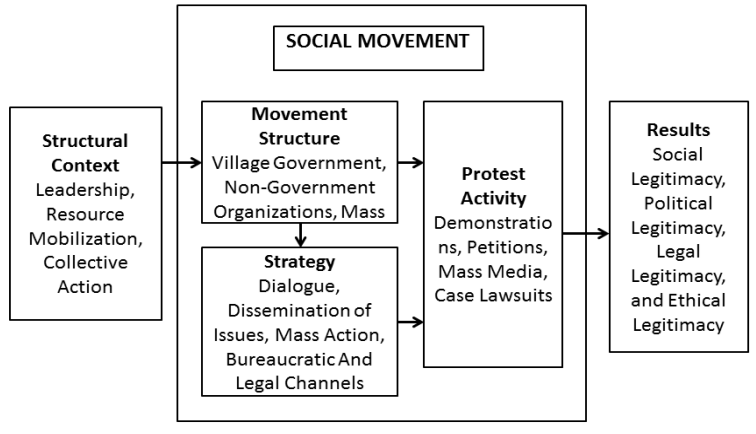

Figure 3 Integrative social movement model

Figure 3. The key element in social movements has the potential for the movement success. Leader involvement and the enthusiasm of collective action have implications for the movement outcome. It is in line with the interrelation of the movement structure, strategy, and protest activities. Democratically, the different aspect in Medali Village community social movement is the support and involvement of the village head. In general, in the form of gaining support, industrial development cases involve bureaucracy and corporations. The democratic element of social movements in the Medali Village is involving the community in the meetings and actions agenda. Also, the social movements' determinant factor is the alignment of the village head (as the element of state apparatus) to its community.

Collective action according to the process of resource mobilization is a series of important events in social movements' success. The success and sustainability of collective action is prerequisite by the leader's achievement in mobilizing others and the resources that can be obtained. Success in mobilizing others is more contributing than mobilizing resources. The seriousness and success of leaders in mobilizing resources and other people are prerequisite by social capabilities and political relations between leaders and other people/those who affected/ participated to the movement.

\section{CONCLUSION}

Based on the leadership of the head of a village in social movements, practically, the leader puts the mobilization of resources and collective action. There are three (3) important element in the structure of social movements: organization, mobilizing structure, and collective action. As the leader of the social movement, the 3 (three) concerns that the head confronted are stakeholders, local governments, and Medali's community. The alignments with the Medali's community are the decision of the village head, in this case, the village official. Based on ethical legitimacy, the head of the village's alignments can justify following the duties and responsibilities of its community. Furthermore, from the ideological comparison, the rubber factory tends to use a capitalist ideology that focuses on profits and neglect the environment. Capitalist ideology tends to fulfill the profit. This capitalist ideology is one of the old social movement's concerns. Whereas, 
[13] T. Simons, "An ecology of ideology: theory and evidence from four populations," Ind. Corp. Chang., vol. 13, no. 1, pp. 33-59, 2004.

[14] M. Locret-collet and S. Springer, "Anarchist Political Ecology : Theoretical Horizons and Empirical Axes," no. McKay 2011, pp. 2014-2017, 2016.

We would like to thank the Rector and Director of Postgraduate University of Muhammadiyah Malang.

\section{REFERENCES}

[1] R. K. Schaeffer, "Social movements and global social change: the rising tide," Lanham: Rowman \& Littlefield., vol. 51, no. 12, pp. 51-7050-51-7050, 2014.

[2] A. Heywood, "Introduction: understanding ideology," Polit. Ideol. an Introd., vol. 1, pp. 1-22, 2007.

[3] S. M. Buechler, "Buechler, Steven M., New Social Movement Theories, Sociological Quarterly, 36:3 (1995:Summer) p.441," Sociol. Q., vol. 3, no. 36, pp. 441-464, 1995.

[4] J. D. McCarthy and M. N. Zald, "Resource mobilization and social movements: A partial theory," Soc. Movements an Organ. Soc. Collect. Essays, vol. 82, no. 6, pp. 15-46, 2017.

[5] S. Vinthagen and A. Johansson, "“Everyday Resistance': Exploration of a Concept and its Theories,” Resist. Stud. Mag., no. 1, pp. 1-46, 2013.

[6] M. Olson, The logic of collective action Cambridge. 1965.

[7] S. Lindenberg, "Coleman, James," no. August, 2015.

[8] J. O. Hertzler, Society in Action: A Study of Social Processes. New York: The Dryden Press, 1954.

[9] K. Knight, "Transformations of the concept of ideology in the twentieth century," Am. Polit. Sci. Rev., vol. 100, no. 4, pp. 619-626, 2006.

[10] T. Eagleton, Ideology : an introduction /Terry Eagleton. 1991.

[11] J. Nescolarde-Selva, J.-L. Usó-Doménech, and H. Gash, "What Are Ideological Systems?," Systems, vol. 5, no. 1, p. 21, 2017.

[12] S. S. Hummel, "E. N. Anderson: Caring for place: ecology, ideology, and emotion in traditional landscape management," Agric. Human Values, vol. 33, no. 2, pp. 495-496, 2016.
[15] J. Goodwin, J. M. Jasper, and F. Polletta, "Emotional Dimensions of Social Movements," in The Blackwell Companion to Social Movements, 2007, pp. 413-432.

[16] J. M. Jasper, "Social Movement Theory Today: Toward a Theory of Action?," Sociol. Compass, vol. 4, no. 11, pp. 965-976, 2010.

[17] J. C. Jenkins, "Social Movements: Resource Mobilization Theory,” Int. Encycl. Soc. Behav. Sci., pp. 14368-14371, 2001.

[18] M. Diani, "Social movements and social capital: a network perspective on movement outcomes," Mobilization An Int. J., vol. 2, no. 2, pp. 129-147, 1997.

[19] C. Fuchs, "The self-organization of social movements," Syst. Pract. Action Res., vol. 19, no. 1, pp. 101-137, 2006.

[20] O. Bina, "The green economy and sustainable development: An uneasy balance?," Environ. Plan. C Gov. Policy, vol. 31, no. 6, pp. 1023-1047, 2013.

[21] N. P. Melville and S. M. Ross, "Information Systems Innovation for Environmental Sustainability Melville/IS Innovation for Environmental Sustainability Quarterly Information Systems Innovation for Environmental Sustainability1," Source MIS Q., vol. 34, no. 1, pp. 1-21, 2010.

[22] R. Thambusamy and A. F. Salam, "Corporate ecological responsiveness, environmental ambidexterity and it-enabled environmental sustainability strategy," in ICIS 2010 Proceedings - Thirty First International Conference on Information Systems, 2010.

[23] E. Ferragina, "The Water Issue in the Mediterranean," 2010.

[24] A. G. Awan, "Relationship Between Environment And Sustainable Economic Development: A Theoretical Approach To Environmental Problems," 2013.

[25] J. W. Creswell, Qualitative Inquiry \& Research Design: choosing among five approaches, vol. 2. 2007. 
[26] D. McAdam, J. D. McCarthy, and M. N. Zald, "Introduction: opportunities mobilizing structures and framing processes," in Comparative Perspectives on Social Movements: Political Opportunities, Mobilizing Structures and Cultural Framings, 1996, pp. 1-22.

[27] S. Rosidi, "Pencemaran Masuk Desa Ladang: Kajian Anatomik Perbenturan Kepentingan dan Pembentukan Tertib Tersiasati antara Pemilik Pabrik Pupuk Cair, Pelaku Pemerintahan Setempat, dan Warga Sekitar". Tidak Dipublikasikan, Magister Sosiologi Universitas Muhammadiyah Malang. 1998.

[28] E. Salim, "Pembangunan Berwawasan Lingkungan". Jakarta: LP3ES. 1986.

[29] J. H. Turner, "The Structure of Sociological Theory". Chicago: The Dorsey Press. Fourth Edition. 1986.

[30] N. L. Cole, "Theories of Ideology". thoughtco.com/ideology-definition-3026356. November 2018. 